\title{
Pesticide residues in soils along railway lines
}

\begin{abstract}
The aim of the study was to examine the content of pesticide residue in soil adherent to the railway track down to the depth of $2 \mathrm{~m}$ below ground. The two lines selected for the examination differed in properties determining pesticide content. To assess the scale of influence of the chemical treatment applied, the selected lines were outside intensive farming areas. The examination consisted of testing the content of 2.4-D, MCPA, carbofuran and atrazine using liquid chromatography, and the content of phenol, cresols, DDT/DDE/DDD, aldrin, dieldrin, endrin and HCH using gas chromatography. The content of 2.4-D, MCPA and phenol was below $0.01 \mathrm{mg} \cdot \mathrm{kg}^{-1}$, cresols - below $0.03 \mathrm{mg} \cdot \mathrm{kg}^{-1}$, DDT/DDE/DDD - below $0.024 \mathrm{mg} \cdot \mathrm{kg}^{-1}$, aldrin and dieldrin - below 0.004 $\mathrm{mg} \cdot \mathrm{kg}^{-1}$, endrin - below $0.005 \mathrm{mg} \cdot \mathrm{kg}^{-1}$, carbofuran and atrazine - below $0.02 \mathrm{mg} \cdot \mathrm{kg}^{-1}, \Sigma \mathrm{HCH}-$ below $0.017 \mathrm{mg} \cdot \mathrm{kg}^{-1}$. The content of pesticide residue in soils along the examined railway lines is lower than that found in arable soils in Poland. No differences in the content of pesticide residue were found between the soils underneath the modernised railway line and the one which had been in use without major alterations to the upper layers for many years. The study found no evidence of any influence of chemical plant removal from railway lines on adjacent lands.
\end{abstract}

Keywords: railway line, pesticides, residue, soil

\section{INTRODUCTION}

The railway network is a system of interconnected railway lines, stations, terminals, and different types of facilities necessary for ensuring its continuous operation. The primary aim of its existence is providing the possibility of safe transportation of persons and items. Railway lines are also places favouring the expansion of certain plant species as a result of spreading diaspores from nearby ecosystems (including arable fields) or as a result of their incidental transport from distant ecosystems (Fornal-Pieniak and Wysocki 2010). The development of the vegetation cover on transport routes depends on specific, difficult habitat conditions, particularly those of soil and moisture, contributing to limiting the abundance and type of the occurring plant species. In such areas, particularly grassy assemblages develop with a substantial contribution of ruderal vegetation and expansive invasive species. The expansion for forest species is also observed (Kryszak et al. 2006, Święs and Majkut 2006). Sowing of slopes of cuttings and embankments (Fig. 1) positively contributes to limiting the abundance of ruderal species and stability of railway facilities, and therefore traffic safety (Koda et. al. 2010). However, the sown plants can negatively affect traffic safety by expanding onto the railway tracks uncontrollably. They can cause blockage of mechanical devices, or disturb the functioning of electrical and electronic devices for controlling railway traffic.
Moreover, the presence of vegetation on the interface of the running surface of the wheel (tread) and top of rail negatively affects the breaking distance of trains. In the period of high temperatures, dry plants - particularly on railway lines with wooden sleepers increase the risk of fires.

The problem with overgrowing railway tracks is observed both on lines exploited for many years and ones recently subject to investment processes. In addition to the elimination of conditions favouring plant vegetation during reconstruction of railway lines, infrastructure managers of the infrastructure also apply mechanical removal of undesired vegetation through its mowing. Mechanical methods do not guarantee efficient elimination of weeds on long sections of railway lines over a short period of time. The problem is particularly important on railway lines with heavy traffic. For reduction of risk to employees and for efficiency, it is popular and effective to chemically remove vegetation by means of devices moving on the railway line. Advantages of this type of devices include direct dosage of plant protection chemicals in a very narrow belt of railway tracks, and the possibility of dynamic unplugging of the dosing devices in places requiring particular protection.

In spite of long-lasting application of chemical vegetation removal on railway lines, no properly planned research has been performed so far concerning soils and pesticide content in railway areas. Lack of 


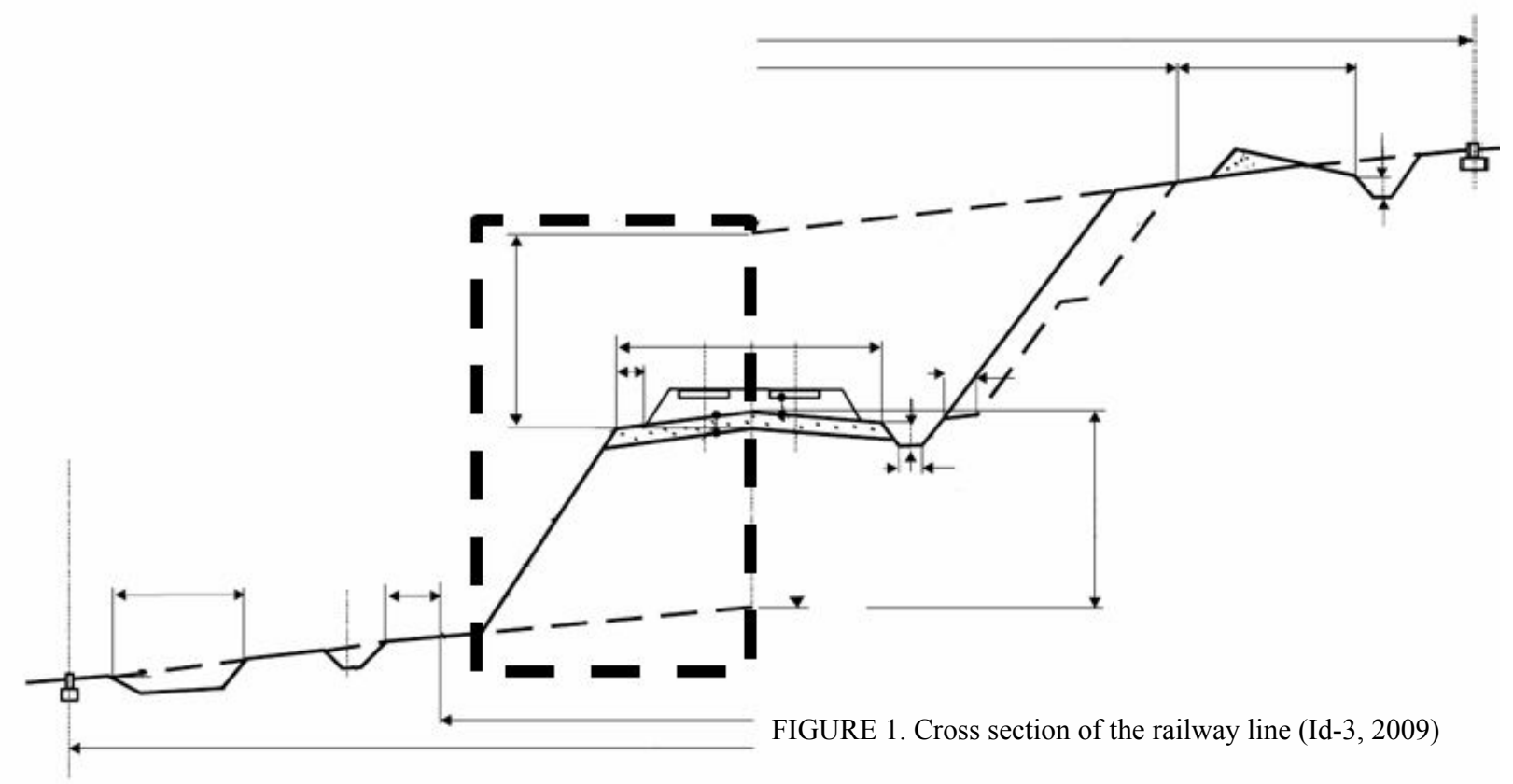

results of soil research and assessment of an increase in pesticide content over time from the construction or reconstruction of a railway line is evident. Research on railway lines to date has been particularly limited to urban and industrial areas, and railway junctions with intensive human impact. This makes it difficult to conduct discussion and compare study results (Zhang et. al. 2012) and to assess the potential effect of arable land, subject to the most intensive application of pesticides. Current studies on contaminants related to railway lines cover particularly polycyclic aromatic hydrocarbons (PAHs) and heavy metals (Malawska and Wiłkomirski 1997, 2000, 2001; Brooks 2004 Bukowiecki et al. 2007, Moret et al. 2007, Akoto et. al. 2008, Liu et al. 2009, Wiłkomirski 2010). Data on contamination with pesticides are limited. Published study results concerning soils on railway lines, in spite of their exclusion from agricultural production, particularly concern the uppermost layer of the soil profile down to a depth of $0.5 \mathrm{~m}$ below ground level, analogically to research on arable soils. Such an approach makes it impossible to assess the degree of contamination of deeper parts of the profile, and transport of contaminants to shallow groundwaters. In the case of a railway line, the upper part of the embankment is not a native formation. They are formations with predefined construction parameters, relevantly compacted and usually elevated above the adherent areas.

The study objective was to fill the information gap and assess pesticide residue in the soil and the underlying formations down to a depth of $2 \mathrm{~m}$ below ground level, directly at the railway track. The study covered two railway lines: one subject to reconstruction affecting the soil profile in the period 2000-2008, and one exploited for many years without changes in the soil profile. The assessment of the scale of effect of chemical treatments performed on railway tracks covered railway lines running outside areas of intensive agricultural production.

\section{STUDY AREA}

The study area covered railway lines included in the trans-European railway system operating international traffic. Samples for analyses were collected in October 2014 on railway line No. 6 Zielonka-Kuźnica Białostocka along the section between the Bug River and railway station Małkinia, and along railway line No. 2 Warszawa Centralna-Terespol on the section from the Mienia River to railway station Mrozy. A single and double track fragment of the railway line was selected, as well as fragments with wooden and concrete sleepers. Both of the railway lines are characterised by a mixed traffic structure combining passenger and freight transport. Railway line No. 6 was constructed in 1862, and line No. 2 in the period 1866-1867. Plant protection chemicals for removal of redundant vegetation had been applied for many years on both lines (PKP Polskie Linie Kolejowe S.A. 2009). Railway line No. 2 in the designated location was subject to reconstruction in the years 2000-2008. Railway line No. 6 is being prepared for construction works on the rail tracks. Both of the lines in the designated locations run across rivers. The designated sections run through forest and arable areas with very low intensity of agricultural activity, outside agglomerations and pollution sources. 


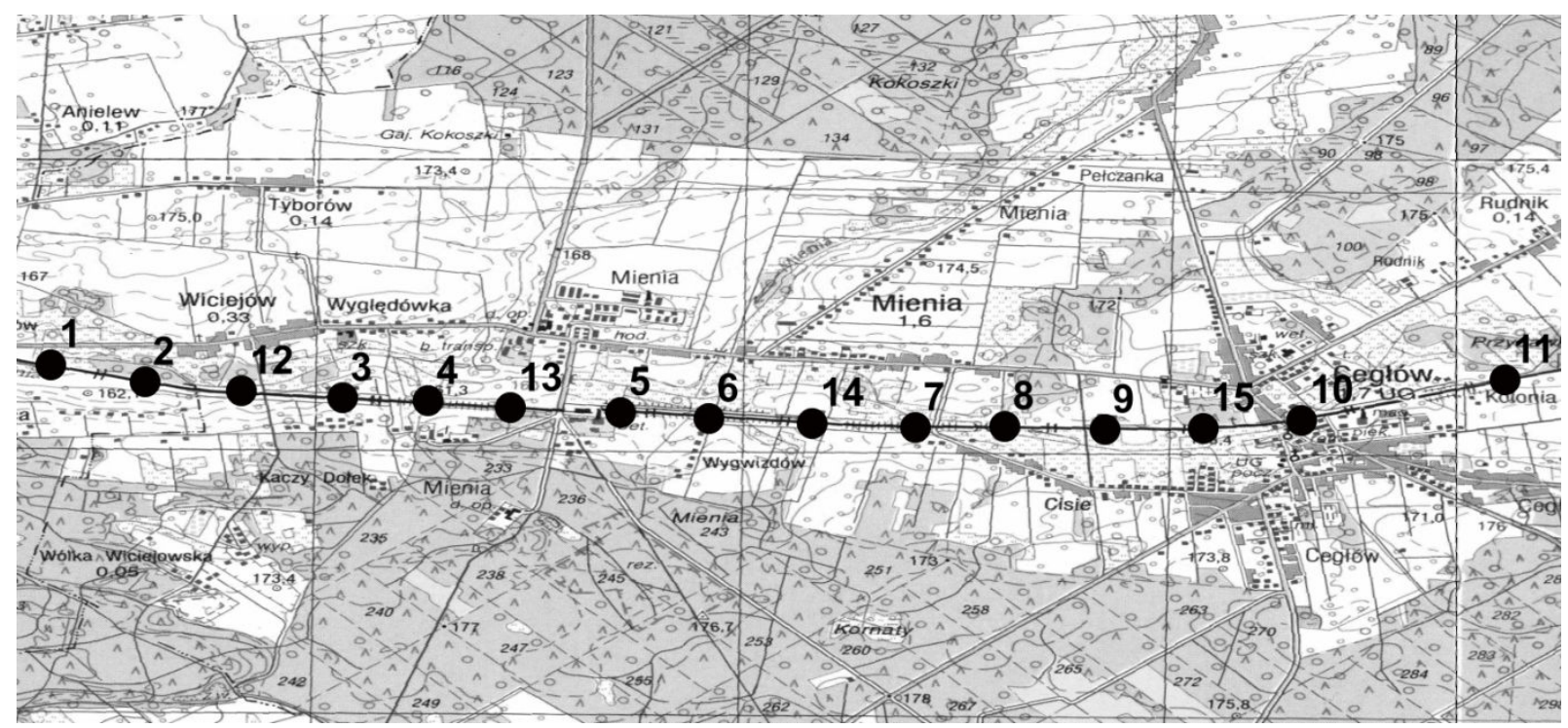

FIGURE 2. Location of sampling sites on railway line No. 2

In each of the designated locations, 15 soil samples were collected alternatively on both sides of railway tracks directly at the track and in front of the drainage system (Fig. 2 and 3). On railway line No. 2, soil samples were collected at distance intervals of $450 \mathrm{~m}$ between the line of traction poles and the drainage system. One sampling site was located outside the drainage system: control sample No. 13 representing areas other than railway areas, where no pesticides were used. In the case of railway line No. 6, samples were collected every $200 \mathrm{~m}$ on average - one (No. 1) sample was collected under the railway bridge directly at the Bug River channel, and another one in the area between railway tracks - intertrack space (No. 12).

\section{MATERIALS AND METHODS}

Sample collection and laboratory analyses were performed by an accredited laboratory as defined in the Act of 30 August 2002 (Ustawa..., 2002). Planning of sample collection was conducted in accordance with guidelines included in norm PN-ISO 10381-1:2008. Samples from a depth of 0-2 $\mathrm{m}$ below ground level were collected in accordance with

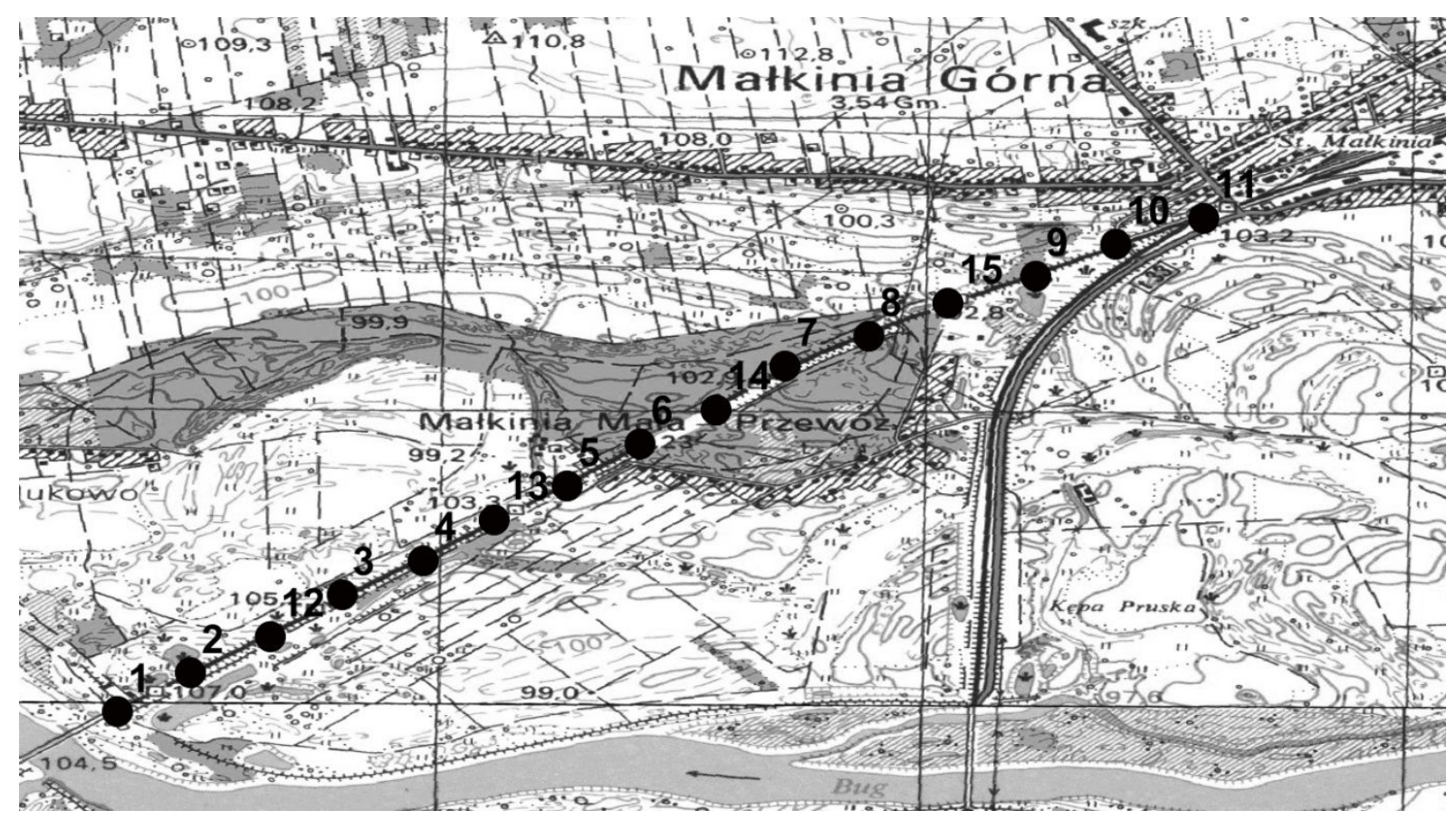

FIGURE 3. Location of sampling sites on railway line No. 6 
guidelines included in norm PN-ISO 10381-5:2009. The representative sample was prepared by mixing and reduction of the collective sample from a depth of 0-2 m below ground level. At each location, one representative sample was taken by means of a manual soil core sampler. The analyses focused on pesticides for which legally accepted contents in soils were determined. For each section of the railway line, in 15 samples, the content of the following substances was determined (Table 1):

- 2.4-dichlorophenoxyacetic acid (2.4-D) and 4-chloro-2-metylphenoxyacetic acid (MCPA) by means of highly efficient liquid chromatography with mass spectrometry;

- phenol and cresols (sum of ortho, meta, para) by means of gas chromatography with mass spectrometry.

For each section of the railway line, in four samples, the content of the following was additionally determined:

- DDT/DDE/DDD, aldrin, dieldrin, endrin, alpha/ beta/gamma $\mathrm{HCH}$ by means of gas chromatography with mass spectrometry;

- carbofuran and atrazine by means of highly efficient liquid chromatography.

\section{RESULTS AND DISCUSSION}

Soil collected along railway lines No. 2 and 6 meets quality standards for transport areas specified in the Regulation of the Minister of the Environment of 9 September 2002 binding on the date of the research, and Regulation of the Minister of the Environment of 1 September 2016 binding on the date of preparation of the article (Table 2-4). In spite of many years of application of plant protection chemicals, the obtained results show that soils related to railway lines meet not only norms for transport areas, but also with a large measure of safety the most rigorous norms specified for areas categorised as arable land.

2.4-dichlorophenoxyacetic acid (2.4-D) and 4-chloro-2-methylphenoxyacetic acid (MCPA) commonly used in herbicides (Sitarek 2004) were reported in amounts lower than $0.01 \mathrm{mg} \cdot \mathrm{kg}^{-1}$. In research conducted in arable fields (soil developed from light and medium loam), Kucharski and Urbanowicz (2008) found the presence of MCPA at a level of up to $0.014 \mathrm{mg} \cdot \mathrm{kg}^{-1}$.

Similarly low contents were observed in the case of phenol and cresols. They varied from $<0.01$ to 0.077 $\mathrm{mg} \cdot \mathrm{kg}^{-1}$ for phenol, and $<0.03 \mathrm{mg} \cdot \mathrm{kg}^{-1}$ for cresols. The amounts were respectively 5000 and 1700 times lower than the accepted values specified in the Regulation of the Minister of the Environment of 9 September 2002 for transport areas (group C). Very low content was recorded for atrazine - below $0.02 \mathrm{mg} \cdot \mathrm{kg}^{-1}$.

The content of the remaining compounds in soil, namely aldrin, dieldrin, $\mathrm{HCH}$ : alpha, beta, gamma was lower than $0.004 \mathrm{mg} \cdot \mathrm{kg}^{-1}$, endrin lower than 0.005

TABLE 1. Characteristics of analytical methods for the determination of pesticide residues (SGS, 2014)

\begin{tabular}{|c|c|c|c|c|c|c|}
\hline Parameter & $\begin{array}{l}\text { Laboratory } \\
\text { equipment }\end{array}$ & $\begin{array}{l}\text { Limit } \\
\text { of detection - } \\
\text { LOD } \\
\left(\mathrm{mg} \cdot \mathrm{kg}^{-1}\right)\end{array}$ & $\begin{array}{l}\text { Limit of } \\
\text { quantification - } \\
\text { LOQ } \\
\left(\mathrm{mg} \cdot \mathrm{kg}^{-1}\right)\end{array}$ & $\begin{array}{l}\text { Analyte } \\
\text { recovery } \\
(\%)\end{array}$ & Precision & Accuracy \\
\hline $2.4-\mathrm{D}$ & \multirow[t]{2}{*}{ LC-MS/MS } & \multirow[t]{2}{*}{0.001} & \multirow[t]{2}{*}{0.01} & 112.8 & 3.19 & 98.5 \\
\hline MCPA & & & & 98.4 & 5.09 & 100 \\
\hline Phenol & \multirow{11}{*}{$\begin{array}{l}\text { GC-MS Agilent } \\
-7890 / 5973 \text { MSD }\end{array}$} & \multirow[t]{2}{*}{0.003} & \multirow[t]{2}{*}{0.01} & 103 & 6.8 & 94.1 \\
\hline Cresols & & & & 108 & 5.4 & 94 \\
\hline DDT & & \multirow[t]{9}{*}{0.001} & \multirow[t]{9}{*}{0.004} & 109 & 5.1 & 96.1 \\
\hline$\underline{\mathrm{DDE}}$ & & & & $82-107$ & $2.4-2.6$ & $95-96.1$ \\
\hline DDD & & & & 87.7 & 3 & 102 \\
\hline Aldrin & & & & 115 & 3.7 & 95.4 \\
\hline Dieldrin & & & & 113 & 4.2 & 101.1 \\
\hline Endrin & & & & 96.7 & 7.6 & 97.2 \\
\hline alpha-HCH & & & & 109 & 4.4 & 96.5 \\
\hline beta-HCH & & & & 109 & 4.8 & 98.5 \\
\hline gamma-HCH & & & & 90.2 & 5.6 & 98.9 \\
\hline Carbofuran & \multirow{2}{*}{$\begin{array}{l}\text { HPCL Shimadzu } \\
\text {-SIL20+MS/MS AB } \\
\text { Sciex QTRAP4000 }\end{array}$} & \multirow[t]{2}{*}{0.002} & \multirow[t]{2}{*}{0.02} & 98.5 & 4.58 & - \\
\hline Atrazine & & & & 97.3 & 3.24 & - \\
\hline
\end{tabular}




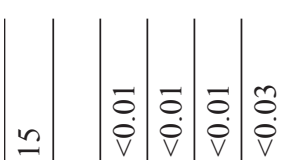

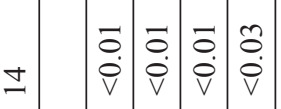

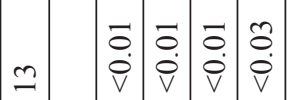

$\simeq \quad \begin{array}{llll}\overrightarrow{0} & \overrightarrow{0} & \overrightarrow{0} & \tilde{\partial} \\ \dot{\vec{v}} & \dot{\vec{v}} & \dot{\vec{v}} & \dot{\vec{v}} \\ & & \end{array}$

$=\quad \begin{array}{llll}\overrightarrow{0} & \overrightarrow{0} & \overrightarrow{0} & \tilde{\partial} \\ \dot{\vec{v}} & \dot{\vec{v}} & \dot{\vec{v}} & \dot{v} \\ v\end{array}$

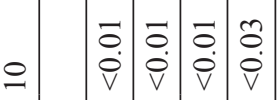

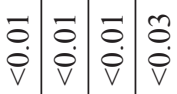

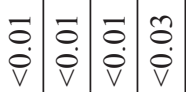

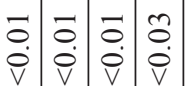

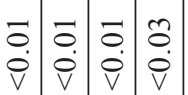

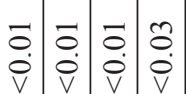

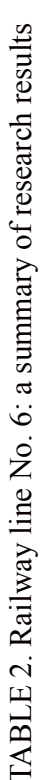

尊

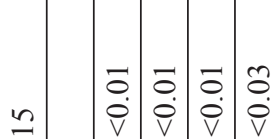

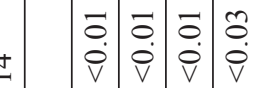

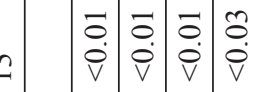

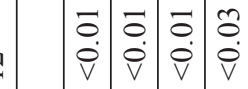

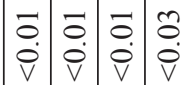

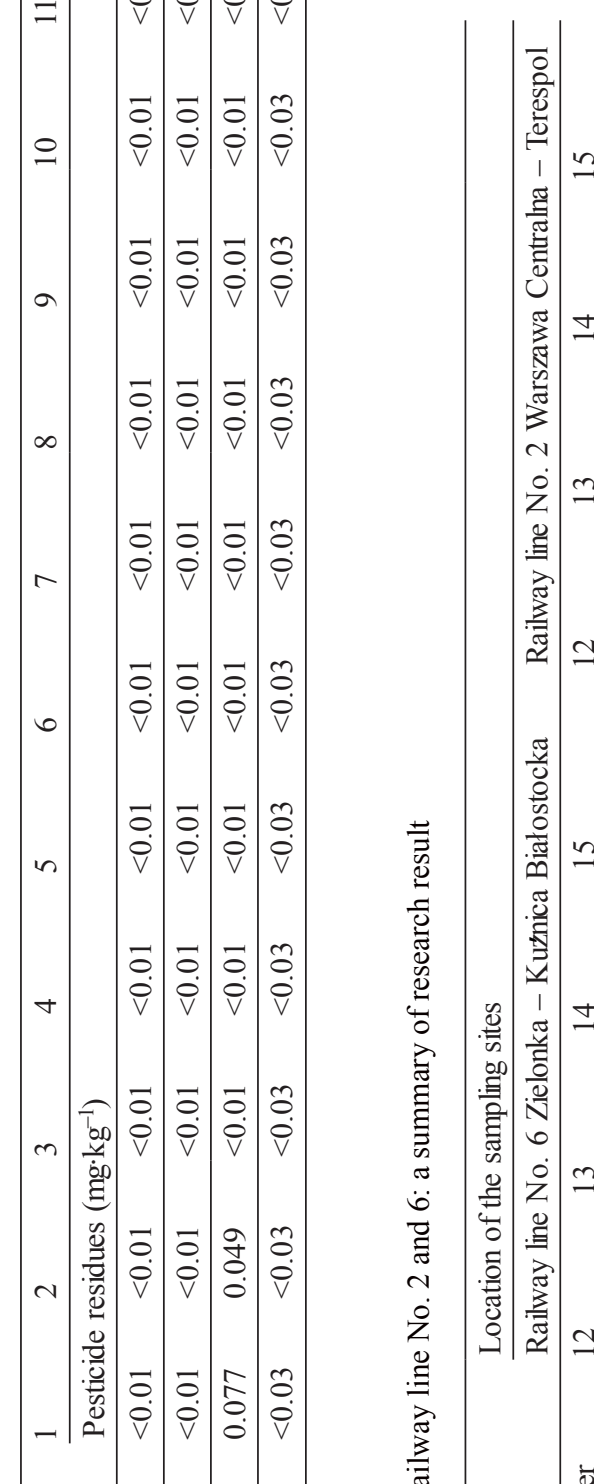

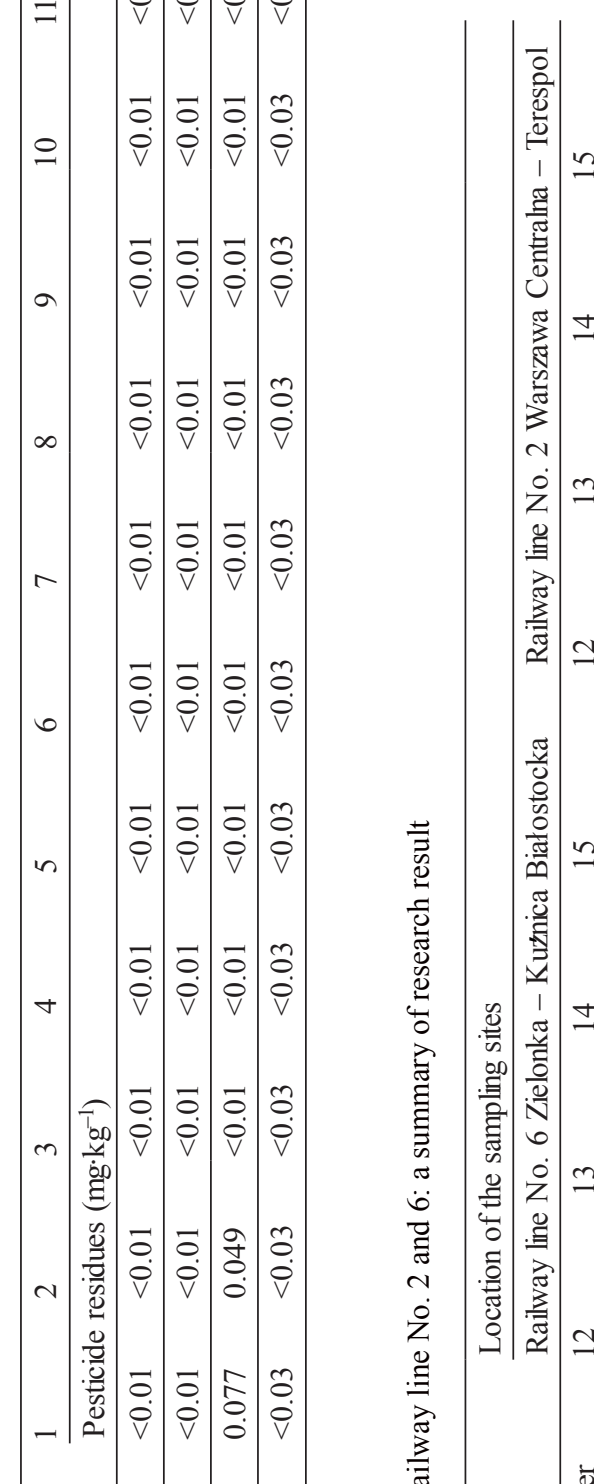

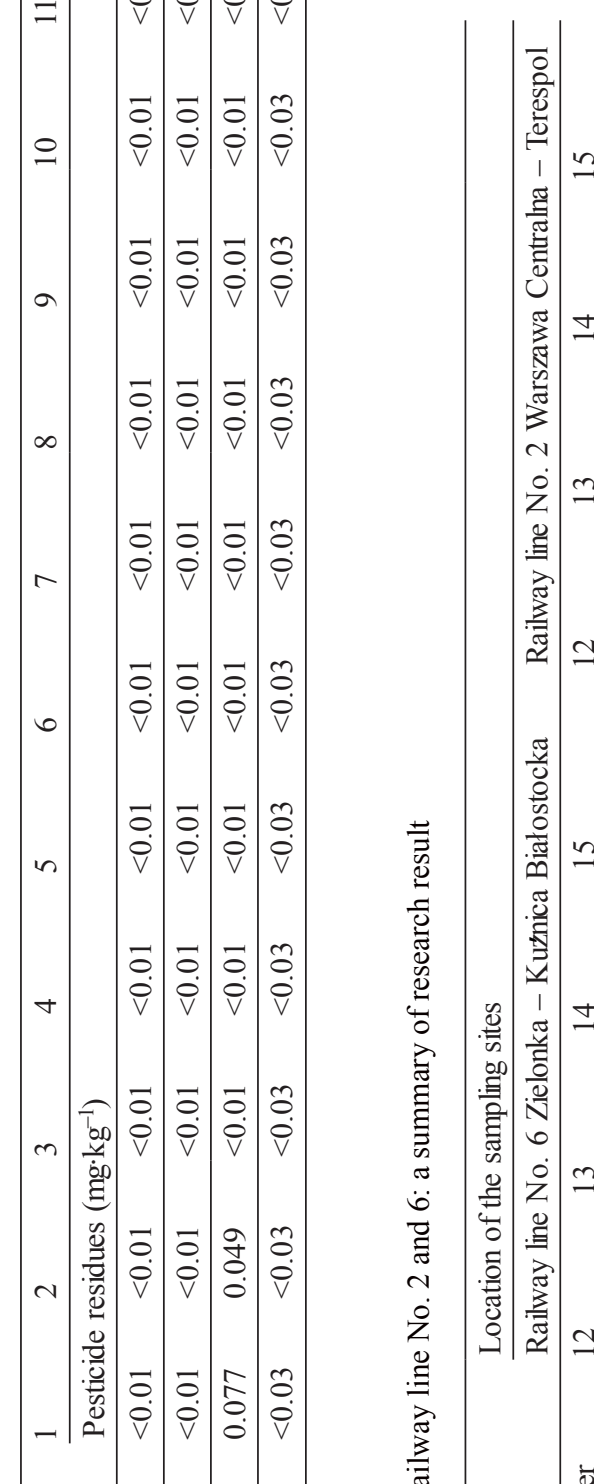

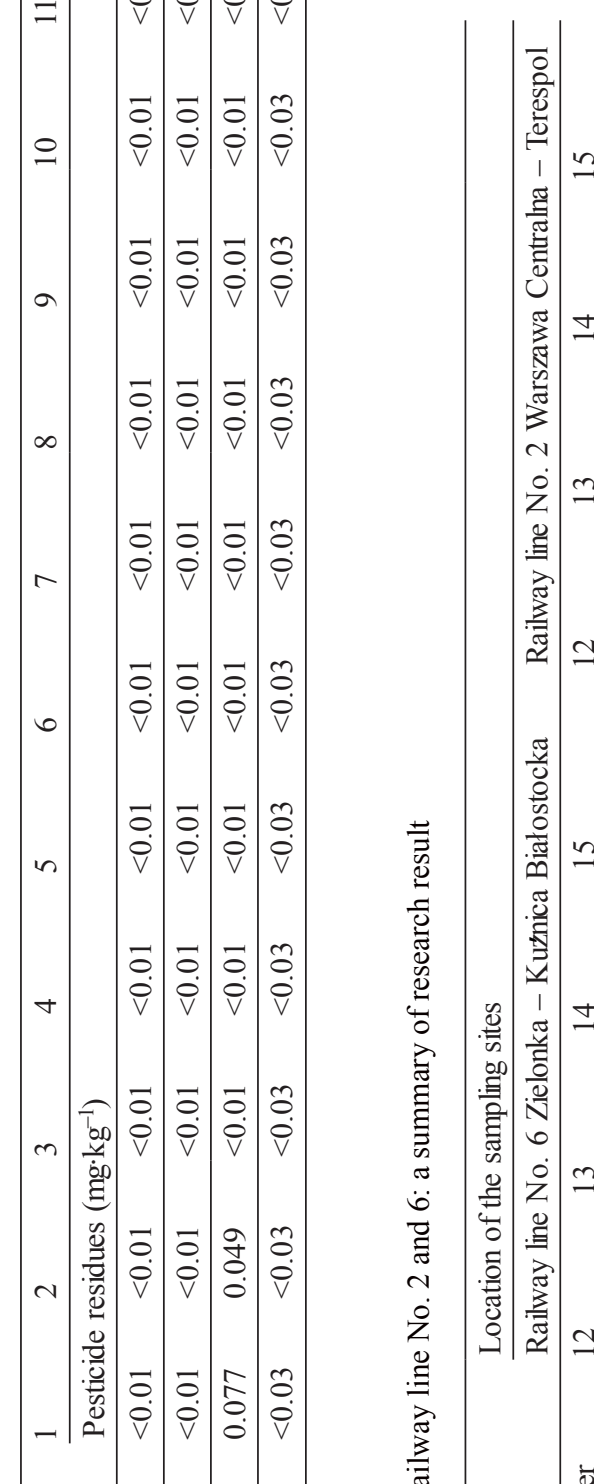

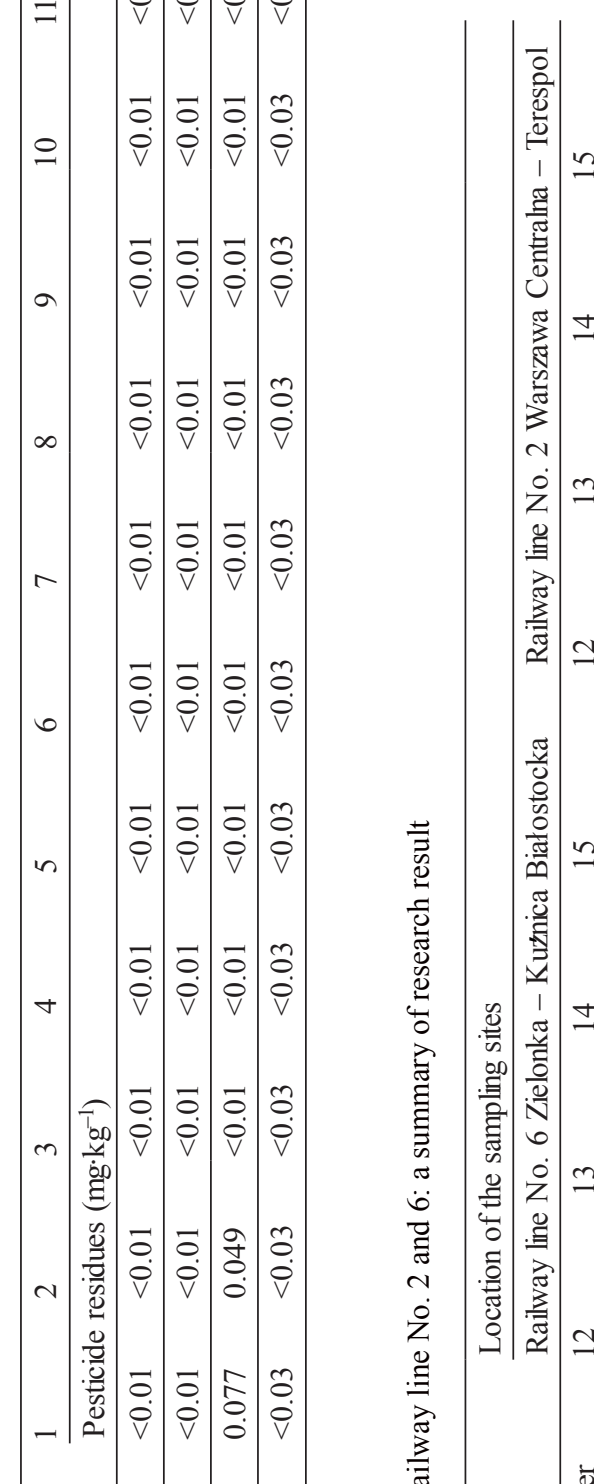

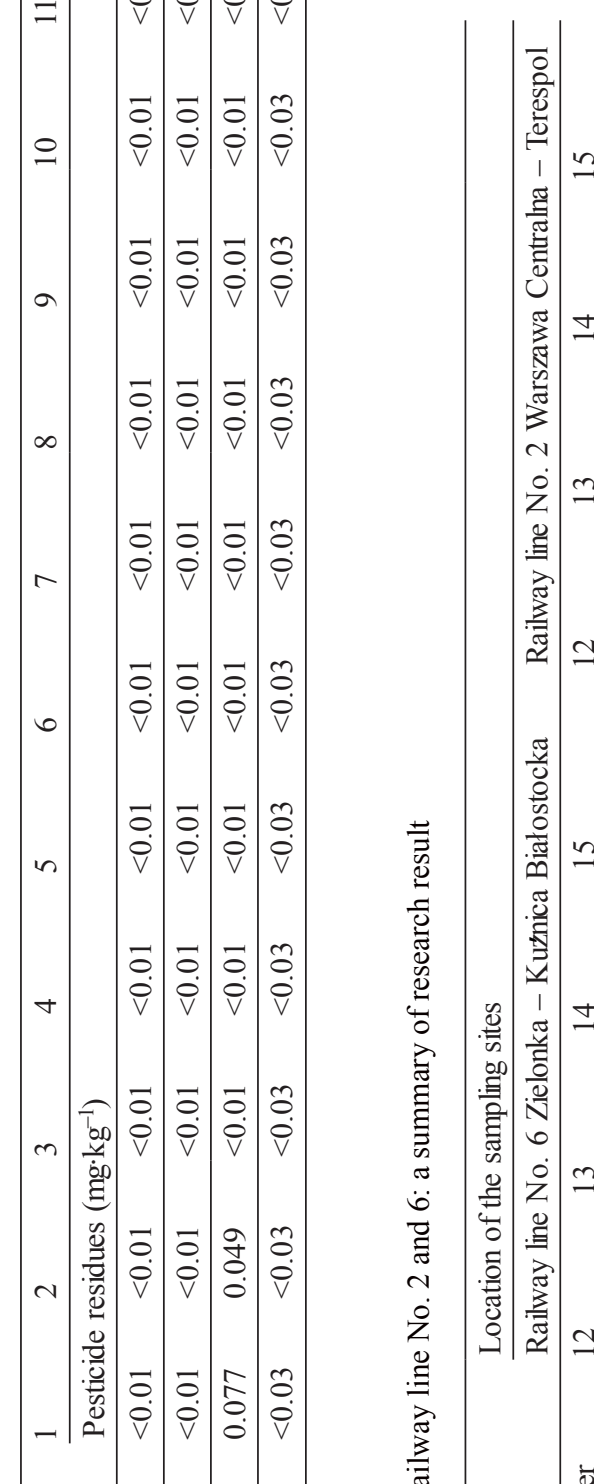

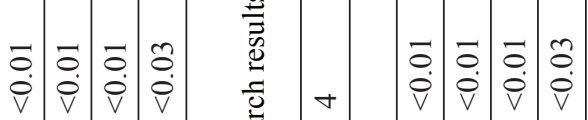

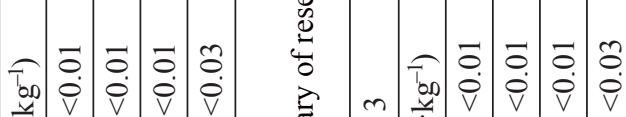

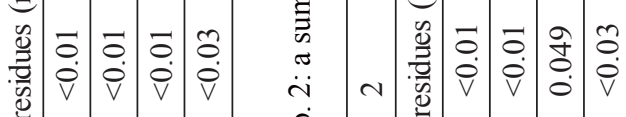

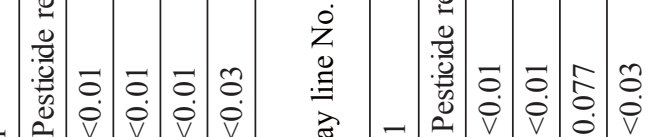

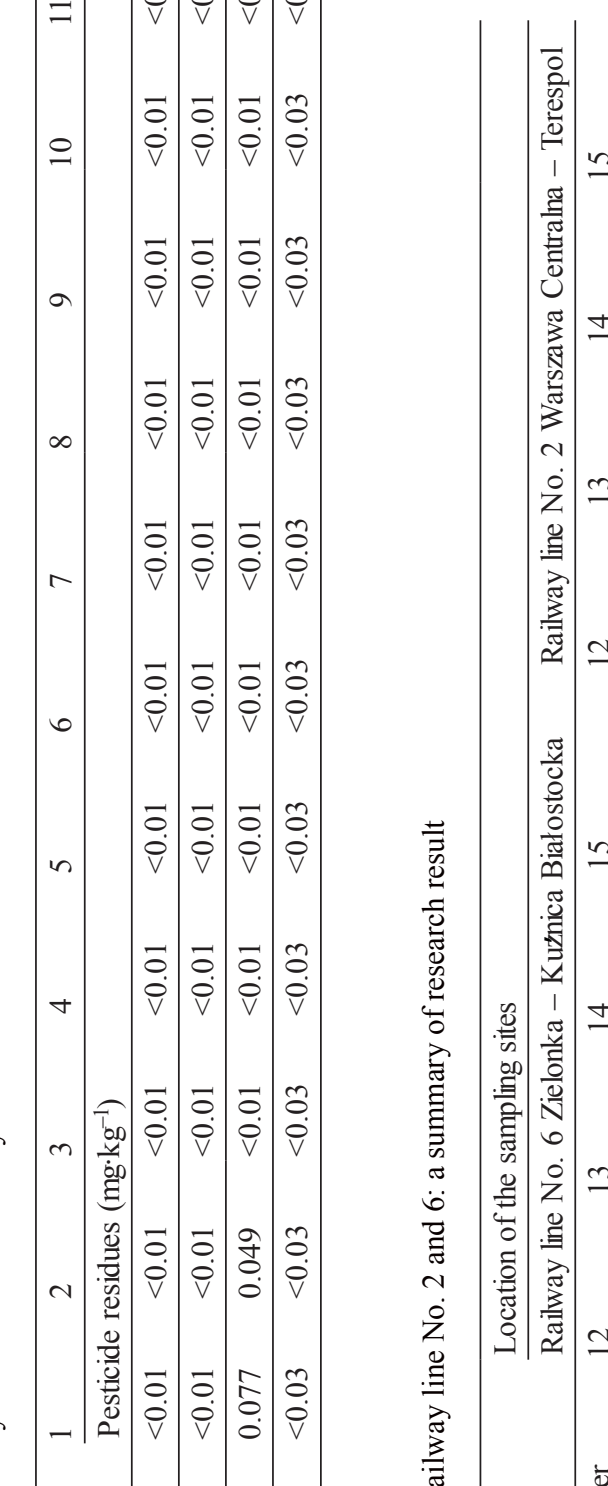

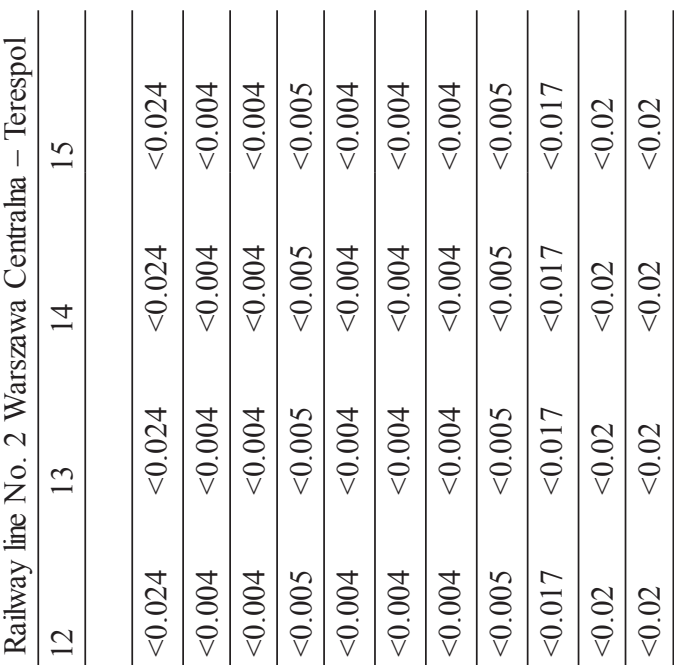

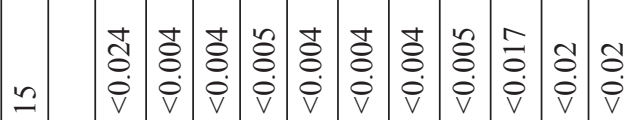

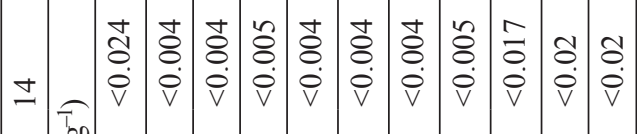

安 
$\mathrm{mg} \cdot \mathrm{kg}^{-1}$, DDT/DDE/DDD (sum of isomers) lower than $0.024 \mathrm{mg} \cdot \mathrm{kg}^{-1}$, and carbofuran lower than $0.02 \mathrm{mg} \cdot \mathrm{kg}^{-1}$.

The comparison of study results concerning soils collected from railway areas with study results referring to 214 samples of arable soils of Poland presented by Maliszewska-Kordybach et al. (2013a, 2013b) shows that the contents of selected pesticide residues are lower in soils from railway areas than the maximum contents reported in arable soils. For example, in arable soils, the maximum content of $\alpha-\mathrm{HCH}$ amounted to $0.151 \mathrm{mg} \cdot \mathrm{kg}^{-1}$, total $\mathrm{HCH}-0.15208$ $\mathrm{mg} \cdot \mathrm{kg}^{-1}$, sum of DDT, DDE, DDD - $0.45009 \mathrm{mg} \cdot \mathrm{kg}^{-1}$, whereas the content in the studied soils under railway lines amounted to $<0.004 \mathrm{mg} \cdot \mathrm{kg}^{-1},<0.017 \mathrm{mg} \cdot \mathrm{kg}^{-1}$, and $<0.024 \mathrm{mg} \cdot \mathrm{kg}^{-1}$, respectively. A similar dependency is observed in the case of forest soils and in urban areas. In the soil of forest complexes, Witczak et al. (2005) observed the content of the componds at a level of up to $0.00823 \mathrm{mg} \cdot \mathrm{kg}^{-1}, 0.00823 \mathrm{mg} \cdot \mathrm{kg}^{-1}$, and $0.1202 \mathrm{mg} \cdot \mathrm{kg}^{-1}$, respectively. Kawano et. al. (2000) determined total $\mathrm{HCH}$ in arable soils at a level of up to $0.027 \mathrm{mg} \cdot \mathrm{kg}^{-1}$, in forest soils up to 0.006 $\mathrm{mg} \cdot \mathrm{kg}^{-1}$, in urban soils up to $0.015 \mathrm{mg} \cdot \mathrm{kg}^{-1}$, and total DDT, DDE, and DDD respectively $1.7 \mathrm{mg} \cdot \mathrm{kg}^{-1}, 0.66$ $\mathrm{mg} \cdot \mathrm{kg}^{-1}$, and $0.67 \mathrm{mg} \cdot \mathrm{kg}^{-1}$.

No differences were determined in the content of the analysed compounds between railway lines No. 2 and 6 (rebuilt line and line exploited for many years with no considerable interference in the surface formations). Replacement of railway ballast coming in direct contact with pesticides, renewal of the subballast, and works in deeper layers of the profile show no considerable effect on the content of residue of plant protection chemicals. The parameters of soil in the direct vicinity of rail tracks subject to many years of treatment with the application of plant protection chemicals are comparable with results for soil near rebuilt railway line where new construction materials were used, having no contact with pesticides before. Therefore, the obtained results do not confirm the occurrence of the phenomenon of contaminant accumulation in soil as a result of many years of application of pesticides.

Constant content of pesticide residue along the analysed sections of railway lines was determined (no spatial variability). This suggests no occurrence of locally intensified eluviation of the studied compounds from the soil. This is caused by the high compaction of soils under the railway line resulting from construction norms for railway structures, and their heating to high temperatures, limiting the process of infiltration of the mixture of water and pesticide into the soil.
No content of the analysed compounds in samples collected on the railway line higher than for those collected in their vicinity was recorded. The fact is confirmed by study results for sample No. 13 collected at railway line No. 2 (located on the side of a forest), representing soils not directly related to railway and agriculture, not subject to the application of pesticides. The sample was collected outside the drainage system of the railway line, constituting the boundary of runoff of precipitation and melt waters as well as shallow groundwaters from the railway line. All of the determined compounds in sample No. 13 as well as in the remaining 14 samples collected on the line occurred on the same level. Lack of an increase in the content of pesticide residue in the direct vicinity of the line results from that fact that in treatments on railway lines, plant protection chemicals were applied very precisely on the narrow belt of land along the railway line. The movement of spraying devices on even railway tracks limits the horizontal movement of the units dispensing the agent, and therefore the effect of wind on its uncontrolled migration outside the rail tracks. Research on quality of waters by the Massachusetts Department of Agricultural Resources (2006) in the place of their crossing by railway lines subject to the application of selected herbicides (more than 300 samples over a period of eight months) showed that the buffer zone of approximately $3 \mathrm{~m}$ around the stream where chemical treatment is discontinued can be sufficient to provide its proper protection against pesticides from railway tracks. It is also important that railway lines are usually perpendicular to streams, and not parallel as it is usually the case on arable land. This eliminates the possibility of fast supply of contaminants with surface flow and waters of fast circulation in the catchment.

\section{CONCLUSIONS}

1. The content of pesticide residue in the soils of the analysed railway area is lower than the acceptable value for transport areas determined by legal regulation.

2. The content of pesticide residue in the soils of the analysed railway area is lower than in the arable soils of Poland analysed by IUNG-PIB.

3. No differences were determined in the content of pesticide residue in soils under the rebuilt line and that subject to many years of exploitation with no substantial interference in the surface formations. No phenomenon of contaminant accumulation in the soil was determined.

4. No change in the content of pesticide residue was observed along the analysed railway lines (no spatial 
variability). This suggests no occurrence of locally intensified eluviation of the analysed compounds from the soil.

5. No effect of treatments of chemical vegetation removal from railway lines on the adherent areas was determined. The content of pesticide residue in soils in the railway area and soils directly outside the railway ditch serving as the drainage system of the railway line and local barrier for the migration of contaminants was determined on a uniform low level.

6. It is recommended to conduct research on pesticide content in the water flowing out from the railway line as a function of time passed since the chemical vegetation removal.

\section{REFERENCES}

Akoto O., Ephraim J.H., Darko G., 2008. Heavy metals pollution in surface soils in the vicinity of abundant railway servicing workshop in Kumasi, Ghana. International Journal of Environmental Research 2(4): 359-364.

Brooks K.M., 2004. Polycyclic aromatic hydrocarbon migration from creosote-treated railway ties into ballast and adjacent wetlands. Research Paper FPL-RP-617, U.S. Department of Agriculture, Forest Service, Forest Products Laboratory: 53 pp.

Bukowiecki N., Gehrig R., Hill M., Lienemann P., Zwicky C.N., Buchmann B., Weingartner E., Baltensberger U., 2007. Iron, manganese and copper emitted by cargo and passenger trains in Zurich (Switzerland): Size-segregated mass concentrations in ambient air. Atmospheric Environment 41(4): 878-889.

Fornal-Pieniak B., Wysocki C., 2010. Flora nasypu nieużytkowanej linii kolejowej w okolicach Sokołowa Podlaskiego (Flora of a non-used railway embankment near Sokołów Podlaski). Water-Environment-Rural Areas. Woda-Środowisko-Obszary Wiejskie 10: 85-94.

Kawano M., Brudnowska B., Falandysz J., Wakimoto T., 2000. Polichlorowane bifenyle i pestycydy chloroorganiczne w glebach w Polsce (Polychlorinated biphenyls and chloroorganic pesticides in soils in Poland. Yearbooks of the National Hygiene Institute). Roczniki Państwowego Zakładu Higieny 51(1) 15-28.

Koda E., Osiński P., Głażewski M., 2010. Agrogeotechniczne umacnianie skarp budowli ziemnych (Agrogeotechnical improvement of earth structure slopes). Scientific Review Environmental Engineering and Development). Przegląd Naukowy - Inżynieria i Kształtowanie Środowiska 4(50): 3647.

Kucharski M., Urbanowicz J., 2008. Badanie pozostałości linuronu i MCPA w glebie i roślinach ziemniaka (Determination of linuron and MCPA residues in soil and potato plants). Bulletin of the Plant Breeding and Acclimatisation Institute. Biuletyn Instytutu Hodowli i Aklimatyzacji Roślin 248: 6166.

Kryszak A., Kryszak J., Czemko M., Kalbarczyk M., 2006. Roślinność nasypów wybranych szlaków kolejowych (Vegetation of embankments along selected railway lines). Zeszyty Naukowe Uniwersytetu Przyrodniczego we Wrocławiu, Rolnictwo (545): 157-164.
Liu H., Chen L.P., Ai Y.W., Yang X., Yu Y.H., Zuo Y.B., Fu G.Y., 2009. Heavy metal contamination in soil alongside mountain railway in Sichuan, China. Environmental Monitoring Assessment 152(1): 25-33.

Malawska M., Wiłkomirski B., 1997. Analiza skażeń gleby polichlorowanymi bifenylami (PCBs) i metalami ciężkimi (Cd, $\mathrm{Pb}$ ) w otoczeniu szlaków kolejowych oraz węzła Iława Główna (Analysis soil pollution by polichlorinated biphenyls (PCBs) and heave metals $(\mathrm{Cd}, \mathrm{Pb})$ along railroads and the Iława Główna hub). Roczniki Państwowego Zakładu Higieny 48(4): 343 349.

Malawska M., Wiłkomirski B., 2000. Soil and plant contamination with heavy metals in the area of the old railway junction Tarnowskie Góry and near two main railway routes. Roczniki Państwowego Zakładu Higieny 51(3): 259-267.

Malawska M., Wiłkomirski B., 2001. An analysis of soil and plant (Taraxacum officinale) contamination with heavy metals and polycyclic aromatic hydrocarbons (PAHs) in the area of the railway junction Iława Główna, Poland. Water, Air and Soil Pollution 127(1): 339-349.

Maliszewska-Kordybach B., Smreczak B., Klimkowicz-Pawlas A., 2013a. Evaluation of the Status of Contamination of Arable Soils in Poland with DDT and HCH Residues; National and Regional Scales. Polish Journal of Environmental Studies 23(1): 139-148.

Maliszewska-Kordybach B., Smreczak B., Klimkowicz-Pawlas A., 2013b. Zagrożenie zanieczyszczeniami chemicznymi gleb na obszarach rolniczych w Polsce w świetle badań IUNG-PIB w Puławach (Threat of chemical contamination in agricultural areas in Poland in the context of research of IUNG-PIB in Puławy). Studia i Raporty IUNG-PIB 35(9): 97-118.

Massachusetts Department of Agricultural Resources, 2006. Surface water monitoring of glyphosate used in rights-of-way railroad vegetation management (2005-2006). Boston: 30 pp.

Moret S., Purcaro G., Lanfranco S.C., 2007. Polycyclic aromatic hydrocarbon (PAH) contentof soil and olives collected in areas contaminated with creosote released from old railway ties. Science of the Total Environment 386(1-3): 1-8.

PN-ISO 10381-1:2008. Jakość gleby - Pobieranie próbek Część 1: Zasady dotyczące opracowywania programów pobierania próbek (PN-ISO 10381-1 Soil quality - Sampling - Part 1: Rules concerning the preparation of sampling programmes).

PN-ISO 10381-5:2009. Jakość gleby - Pobieranie próbek - Część 5: Zasady postępowania podczas badań terenów miejskich oraz przemysłowych pod kątem zanieczyszczenia gleby (PN-ISO 10381-5:2009. Soil quality - Sampling - Part 5: Rules of proceedings in research on urban and industrial areas in terms of soil contamination).

PKP Polskie Linie Kolejowe S.A. 2009. Warunki techniczne utrzymania podtorza kolejowego Id-3 (Technical conditions of maintenance of railway track bed Id-3) (www.plk-sa.pl/dlaklientow-i-kontrahentow/akty-prawne-i-przepisy/instrukcjepkp-polskie-linie-kolejowe-sa/instrukcje-z-mozliwoscia-podgladu/

Rozporządzenie Ministra Środowiska z dnia 9 września 2002 r. w sprawie standardów jakości gleby oraz standardów jakości ziemi (Dz.U. $2002 \mathrm{nr} 165$ poz. 1359) (Regulation of the Minister of the Environment of 9 September 2002 on soil quality standards and earth quality standards (Journal of Laws 2002 No. 165 item 1359). 
Rozporządzenie Ministra Środowiska z dnia 1 września 2016 r. w sprawie sposobu prowadzenia oceny zanieczyszczenia powierzchni ziemi (Dz.U. 2016 poz. 1395) (Regulation of the Minister of the Environment of 1 September 2016 on the way of assessment of contamination of the earth surface (Journal of Laws 2016 item 1395)).

SGS Polska na zlecenie PKP Polskie Linie Kolejowe S.A., 2014. Ekspertyza dotycząca wpływu linii kolejowych na zanieczyszczenie powierzchni ziemi (niepublikowane) (SGS Polska on commission of PKP Polskie Linie Kolejowe S.A., 2014. Expertise concerning the effect of railway lines on earth surface contamination (unpublished)).

Sitarek K., 2004. 2,4-D-kwas (2,4-dichlorofenoksy)octowy Dokumentacja proponowanych wartości dopuszczalnych wielkości narażenia zawodowego (2.4-D (2.4-dichlorophenoxy) acetic acid - Documentation of the proposed acceptable values of occupational exposure. Basics and Methods of Assessment of the Work Environment). Podstawy i Metody Oceny Środowiska Pracy 1(39): 65-89.

Święs F., Majkut A., 2006. Rzadsze rośliny naczyniowe terenów kolejowych w określonych regionach Kotliny Sandomierskiej. Cz. 1. Nizina Nadwiślańska, część północna (Rare vascular plants of the railway areas in specific regions of the Sandomierz Basin. Part 1. Vistula Lowland, northern part). Annales Universitatis Marie Curie-Skłodowska Lublin 61: 19-43.
Ustawa z dnia 30 sierpnia 2002 r. o systemie oceny zgodności (tekst jed.: Dz. U. 2016 r. poz. 1228) (Act of 30 August 2002 on the compliance assessment system (consolidated text, Journal of Laws 2016, item 1228).

Wiłkomirski B., 2010. „Stoi na stacji lokomotywa”, czyli zanieczyszczenia środowiska związane z transportem kolejowym ("The locomotive stands on the station", that is environmental pollution connected with railway transport). Rocznik Świętokrzyski. Ser. B - Nauki Przyrodnicze 31: 85-94.

Witczak A., Tomza A., Ciereszko W., Borowicz J., 2005. Porównanie zawartości wybranych pestycydów chloroorganicznych w korze sosny (Pinus sylvestris L.) oraz w glebie na terenie leśnictwa Moracz (The comparison of contents of organochlorine pesticides in pine bark (Pinus sylvestris L.) and soil within the Moracz forest district). Acta Scientiarum Polonorum. Silvarum Colendarum Ratio et Industria Lignaria 4(2): 135-146.

Zhang H., Wang Z., Zhang Y., Hu Z., 2012. The effects of the Qinghai-Tibet railway on heavy metals enrichment in soils. Science of the Total Environment 439: 240-248.

Received: November 2, 2016

Accepted: December 18, 2017

Associated editor: B. Rutkowska

\section{Pozostałości pestycydów w glebach wzdłuż linii kolejowych}

Streszczenie: Celem badań była ocena zawartości pozostałości pestycydów w glebie i utworach podściełających do głębokości $2 \mathrm{~m}$ p.p.t. bezpośrednio przy torze kolejowym. Do badań wytypowano dwie linie kolejowe przebiegające poza obszarami intensywnej produkcji rolnej. Oznaczono zawartość 2,4-D, MCPA, karbofuranu, atrazyny z wykorzystaniem chromatografii cieczowej, fenolu, krezoli, DDT/DDE/DDD, aldryny, dieldryny, endryny, HCH z wykorzystaniem chromatografii gazowej. Zawartość 2,4-D, MCPA, fenolu była poniżej $0,01 \mathrm{mg} \cdot \mathrm{kg}^{-1}$, krezoli poniżej $0,03 \mathrm{mg} \cdot \mathrm{kg}^{-1}$, DDT/DDE/DDD poniżej $0,024 \mathrm{mg} \cdot \mathrm{kg}^{-1}$, aldryny i dieldryny poniżej $0,004 \mathrm{mg} \cdot \mathrm{kg}^{-1}$, endryny poniżej $0,005 \mathrm{mg} \cdot \mathrm{kg}^{-1}$, karbofuranu i atrazyny poniżej $0,02 \mathrm{mg} \cdot \mathrm{kg}^{-1}, \Sigma \mathrm{HCH}$ poniżej $0,017 \mathrm{mg} \cdot \mathrm{kg}^{-1}$. Poziom pozostałości pestycydów w glebach wzdłuż badanych linii kolejowych był niższy niż w glebach ornych Polski. Nie stwierdzono różnic w zawartości pozostałości pestycydów w glebach pod linią zmodernizowaną i eksploatowaną od wielu lat bez znaczącej ingerencji w utwory powierzchniowe. Nie stwierdzono oddziaływania zabiegów chemicznego usuwania roślinności z linii kolejowych na tereny sąsiednie.

Słowa kluczowe: linia kolejowa, pestycydy, pozostałości, gleba 